\title{
KONTRIBUSI STATUS SOSIAL EKONOMI, MOTIVASI BERPRESTASI, BUDAYA SEKOLAH, DAN DISIPLIN BELAJAR, TERHADAP HASIL BELAJAR IPS EKONOMI PADA SISWA KELAS IX DI SMP KECAMATAN GEROKGAK
}

\author{
Ida Bagus Oka Mahendra, I Made Yudana, Dewa Gede Hendra Divayana \\ Program Studi Administrasi Pendidikan, Program Pascasarjana \\ Universitas Pendidikan Ganesha \\ Singaraja, Indonesia

\begin{abstract}
e-mail: \{oka.mahendra@pasca.undiksha.ac.id,made.yudana@undiksha.ac.id, hendra.divayana@undiksha.ac.id \}
\end{abstract}

\begin{abstract}
Abstrak
Penelitian ini bertujuan untuk mengetahui kontribusi status sosial ekonomi, motivasi berprestasi, budaya sekolah, dan disiplin belajar, terhadap hasil belajar IPS Ekonomi pada siswa kelas IX di SMP Kecamatan Gerokgak. Penelitian ini adalah penelitian "ex-post facto" dengan besar sampel 300 orang. Data dikumpulkan dengan kuesioner dan dokumen. Analisis data dilakukan dengan teknik regresi sederhana, regresi ganda, dan korelasi parsial. Hasil penelitian menunjukkan bahwa: 1) ada kontribusi yang signifikan antara status sosial ekonomi terhadap hasil belajar IPS Ekonomi pada siswa kelas IX di SMP Kecamatan Gerokgak dengan koefisien korelasi sebesar 0,408 dan sumbangan efektifnya sebesar 8,64\%. 2) ada kontribusi yang signifikan antara motivasi berprestasi terhadap hasil belajar IPS Ekonomi pada siswa kelas IX di SMP Kecamatan Gerokgak. dengan koefisien korelasi sebesar 0,406 dan sumbangan efektifnya sebesar 9,45\%. 3) ada kontriubusi yang signifikan antara budaya sekolah terhadap hasil belajar IPS Ekonomi pada siswa kelas IX di SMP Kecamatan Gerokgak dengan koefisien korelasi sebesar 0,339 dan sumbangan efektifnya sebesar $6,55 \%$. 4) ada kontriubusi yang signifikan antara disiplin belajar terhadap hasil belajar IPS Ekonomi pada siswa kelas IX di SMP Kecamatan Gerokgak dengan koefisien korelasi sebesar 0,219 dan sumbangan efektifnya sebesar 2,95\%. 5) secara bersamasama, ada kontribusi yang signifikan antara status sosial ekonomi, motivasi berprestasi, budaya sekolah, dan disiplin belajar terhadap hasil belajar IPS Ekonomi pada siswa kelas IX di SMP Kecamatan Gerokgak dengan koefisien korelasi ganda sebesar 0,525 dan kontribusinya sebesar 27,6\% terhadap hasil belajar IPS Ekonomi siswa kelas IX di SMP Kecamatan Gerokgak.
\end{abstract}

Kata kunci: status sosial ekonomi, motivasi berprestasi, budaya sekolah, disiplin belajar, hasil belajar IPS Ekonomi

\begin{abstract}
This study aims to determine the contribution of socioeconomic status, achievement motivation, school culture, and discipline of learning, to the results of learning IPS Economics in grade IX students in junior high school Gerokgak District. This study is an "ex-post facto" study with a sample size of 300 people. Data were collected with questionnaires and documents. Data analysis was performed by simple regression, multiple regression, and partial correlation. The results showed that: 1) there was a significant contribution between the socioeconomic status of the IPS Economics learning outcomes in grade IX students in junior high school Gerokgak with correlation coefficient of 0.408 and effective contribution of $8.64 \%$. 2) there is a significant contribution between achievement motivation toward IPS Economic learning outcomes in grade IX students in junior high school Gerokgak District. with a correlation coefficient of 0.406 and an effective contribution of $9.45 \%$. 3) there is significant contriubution between school culture on IPS Economic learning result in grade IX students in junior high school Gerokgak District with correlation coefficient of 0,339 and effective contribution equal to 6,55\%. 4) there is significant contriubution between learning discipline to IPS Economics learning result in grade IX students in junior high school of Gerokgak sub district with correlation coefficient 0,219 and effective contribution $2,95 \% .5)$ simultaneously, there is a significant contribution between socioeconomic status, achievement motivation, school culture, and learning discipline of IPS Economics learning outcomes in grade IX
\end{abstract}


students in junior high school Gerokgak District with double correlation coefficient of 0,525 and contribution of $27,6 \%$ on the results of study IPS Economics class IX students in junior high school Gerokgak District.

Keywords: socioeconomic status, achievement motivation, school culture, learning discipline, IPS Economics learning result

\section{PENDAHULUAN}

Hasil belajar memiliki hubungan dengan masalah pendidikan orang tua, hal ini membawa dampak positif pada peserta didik, keluarga dan terhadap masyarakat sekitar. Tingkat pendidikan orang tua yang berbeda-beda dari yang tidak tamat SD, tamat SD, SMP, SMA dan Perguruan Tinggi juga mempengaruhi prestasi belajar siswa. Orang tua yang memiliki tingkat pendidikan tinggi bisanya memiliki cita-cita yang tinggi pula terhadap pendidikan anak-anaknya. Mereka menginginkan pendidikan anak- anaknya lebih tinggi atau setidaknya sama dengan pendidikan orang tuanya. Cita-cita dan dorongan ini akan mempengaruhi sikap dan perhatian orang tua terhadap keberhasilan anak- anaknya di sekolah.

Terkait dengan itu, perhatian orang tua dalam kegiatan belajar anak di rumah akan memberikan motivasi bagi diri anak. Faktor keterlibatan orang tua dalam mendidik anak termasuk faktor yang sangat penting. Bloom (dalam Hasbullah: 2002) menyatakan bahwa keterlibatan orang tua dalam mendidik anak menjadi penyebab kesuksesan belajar anak. Sedangkan sekolah sebenarnya adalah suplemen dari rumah, artinya kedudukan sekolah pada dasarnya adalah menopang pendidikan di rumah.

Selain intensitas pendidikan oleh orang tua dalam kegiatan belajar anak yang secara teori akan memotivasi belajar anak/siswa dan dapat mempengaruhi prestasi belajar siswa, maka faktor status sosial ekonomi orang tua diduga juga mendukung prestasi belajar siswa. Karena jika status sosial ekonomi orang tua tinggi ataupun sedang maka akan bisa memenuhi berbagai fasilitas belajar yang diperlukan anaknya. Dengan fasilitas belajar yang bisa terpenuhi maka anak/siswa dapat melakukan kegiatan belajar dengan baik yang pada akhirnya akan memberikan dampak positif bagi prestasi belajar yang diraihnya. Status sosial ekonomi menurut Walter (1995) adalah "socioeconomic status refers to some combination of familial income, education, and employment. Sementara Woolfolk (2000) mengatakan the term used by sociologists for variations in wealth, power, and prestige is a socioeconomic status". Stratifikasi sosial sebagai suatu keberadaan kelompok-kelompok bertingkat dalam masyarakat tertentu, yang anggota-anggotanya memiliki kekuasaan, hak-hak istimewa, dan prestise yang berbeda. Stratifikasi sosial masyarakat Indonesia menggunakan indikator suku bangsa, latar belakang keluarga, pendidikan, pekerjaan dan kekayaan material. Secara konkrit faktor penentu seseorang dalam kelompok strata sosial, dapat diamati dari kekayaan dan penghasilan, pekerjaan, pendidikannya. Ketiga aspek inilah yang disebut dengan determin stratifikasi sosial.

Dapat disimpulkan bahwa stratifikasi sosial atau status sosial ekonomi seseorang didasarkan pada pekerjaan, penghasilan, pendidikan dan jumlah tanggungan keluarga. Status sosial ekonomi orang tua tentunya akan mendukung pemberian fasilitas belajar anak yang diperlukan. Dengan fasilitas belajar anak yang terpenuhi maka kemudahan belajar bagi anak akan tercipta, serta akan tercipta motivasi belajar dan anak akan memiliki prestasi belajar yang lebih baik.

Motivasi berprestasi erat kakitannya dengan motivasi belajar, yang mana motivasi belajar yang kuat membuat siswa mau belajar, mau berpikir dan bekerja keras. Slavin (2001) menyatakan bahwa motif yang kuat membuat si anak tidak lekas putus asa, pantang mundur, pantang berhenti di tengah jalan, mau belajar, menyebabkan si anak mau berpikir dan bekerja keras, mempunyai tujuan yang jelas (jelas cita-citanya atau kebutuhannya). Sedangkan anak yang mempunyai motif lemah akan cepat melepaskan tujuan.

Setiap lembaga pendidikan, sebagai mana setiap individu dalam sebuah lembaga pendidikan berbeda antara satu sama lain. Seperti layaknya manusia, sebuah sekolah memiliki getaran dan jiwa sendiri. Masing-masing mengespresikan rasa sendiri yang penting berbeda 
satu sama lainnya. Getaran tersebut berasal dari lingkungan sekolah yang gilirannya menciptakan budaya sebuah lembaga pendidikan.

Dari uraian tersebut, maka dapat memberikan pemahaman bahwa budaya organisasi sekolah akan dapat menjelaskan bagaimana sekolah berfungsi, seperti apakah mekanisme internal sekolah yang terjadi, karena para warga sekolah masuk ke sekolah dengan bekal budaya yang mereka miliki, sebagian bersifat positif, yaitu yang mendukung peningkatan kualitas pembelajaran. Namun ada yang negatif, yaitu yang menghambat usaha peningkatan kualitas pembelajaran.

Perilaku disiplin sangatlah diperlukan oleh siapapun, dimanapun dan kapanpun, begitu juga siswa yang harus disiplin dalam mentaati tata tertib sekolah, ketaatan dalam belajar, disiplin dalam mengerjakan tugas dan disiplin dalam belajar di rumah sehingga tujuan pembelajaran dapat tercapai.

Seorang siswa perlu memiliki sikap disiplin dengan melakukan latihan yang memperkuat dirinya sendiri untuk selalu terbiasa patuh dan mempertinggi daya kendali diri. Disiplin Belajar adalah pengendalian diri mahasiswa terhadap bentuk-bentuk aturan baik tertulis maupun tidak tertulis yang telah diterapkan oleh mahasiswa yang bersangkutan maupun berasal dari luar serta bentuk kesadaran akan tugas dan tanggung jawabnya sebagai pelajar, baik disiplin di rumah maupun di kampus dengan tidak melakukan sesuatu yang dapat merugikan tujuan dari proses belajarnya. Menurut Suharsimi (2003: 114) "disiplin merupakan sesuatu yang berkenaan dengan pengendalian diri seseorang terhadap bentukbentuk aturan di mana aturan tersebut diterapkan oleh orang yang bersangkutan maupun berasal dari luar". Sikap disiplin yang timbul dari kesadarannya sendiri akan dapat lebih memacu dan tahan lama dibandingkan dengan sikap disiplin yang timbul karena adanya pengawasan dari orang lain. Mahasiswa yang memiliki disiplin yang tinggi akan belajar dengan baik dan teratur sehingga akan menghasilkan prestasi yang baik.

Sekolah merupakan tempat berlangsungnya kegiatan belajar mengajar. Belajar dan mengajar tidak hanya dimaknai sebagai kegiatan transfer ilmu pengetahuan dari guru ke siswa. Berbagai kegiatan seperti bagaimana membiasakan seluruh warga sekolah disiplin dan patuh terhadap peraturan yang berlaku di sekolah, saling menghormati, membiasakan hidup bersih dan sehat serta memiliki semangat berkompetisi secara fair dan sejenisnya merupakan kebiasaan yang harus ditumbuhkan di lingkungan sekolah sehari-hari.

Zamroni (2003: 149) mengatakan bahwa kebiasaan-kebiasaan, nilai-nilai, norma, ritual, mitos yang dibentuk dalam perjalanan panjang sekolah disebut budaya sekolah. Budaya sekolah dipegang bersama oleh kepala sekolah, guru, staf aministrasi, dan siswa sebagai dasar mereka dalam memahami dan memecahkan berbagai persoalan yang muncul di sekolah. Sekolah menjadi wadah utama dalam transmisi kultural antar generasi.

Untuk bisa mengukur keberhasilan tingkat pendidikan, salah satu indikatornya adalah hasil belajar. Menurut Dimyati dan Mudjiono (1999:250) bahwa: "hasil belajar merupakan hal yang dapat dipandang dari dua sisi yaitu sisi siswa dan dari sisi guru. Dari sisi siswa, hasil belajar merupakan tingkat perkembangan mental yang lebih baik bila dibandingkan pada saat sebelum belajar. Tingkat perkembangan mental tersebut terwujud pada jenis-jenis ranah kognitif, afektif, dan psikomotor. Sedangkan dari sisi guru, hasil belajar merupakan saat terselesaikannya bahan pelajaran".

Berdasarkan pendapat di atas dapat dijelaskan bahwa hasil belajar merupakan capaian yang diperoleh siswa setelah mengikuti serangkaian proses belajar. Hasil tersebut berupa perubahan tingkah laku siswa dari yang tadinya tidak tahu menjadi tahu. Hal ini sejalan dengan pendapat Oemar Hamalik (2006:30), "hasil belajar adalah bila seseorang telah belajar akan terjadi perubahan tingkah laku pada orang tersebut, misalnya dari tidak tahu menjadi tahu, dan dari tidak mengerti menjadi mengerti".

Dalam hal ini tingkat keberhasilan yang ingin diukur adalah hasil belajar IPS ekonomi kelas IX. Tapi kenyataan yang terjadi berdasarkan hasil tes peminatan awal di SMA N 1 
Gerokgak, rata-rata nilai mata pelajaran IPS Ekonomi masih rendah. Siswa yang mengikuti TPA berasal dari seluruh SMP Negeri Kecamatan Gerokgak.

Oleh karena itu peneliti ingin mengetahui kontribusi status sosial ekonomi, motivasi berprestasi, budaya sekolah, dan disiplin belajar, terhadap hasil belajar IPS Ekonomi pada siswa kelas IX di SMP Kecamatan Gerokgak.

\section{METODE PENELITIAN}

Penelitian ini merupakan penelitian ex-post facto atau penelitian non- eksperimen (empirik). Penelitian non eksperimen merupakan suatu pendekatan pada subyek penelitian untuk meneliti yang telah dimiliki oleh subyek penelitian secara wajar tanpa adanya usaha sengaja memberikan perlakuan untuk memunculkan variable yang ingin diteliti.(Dantes, 2012: 59).

Dalam penelitian ex-post fakto yang berbentuk korelasional, variable-variabel bebasnya tidak dikontrol sacara langsung karena sebelumnya sudah ada, jadi tidak dapat dimanipulasi. Ex-post fakto adalah penelitan empiris sistematis, dimana ilmuwan tidak mengendalikan variable bebas secara langsung karena perwujudan variable tersebut telah terjadi, atau karena variable tersebut pada dasarnya memang tidak dimanipulasi. Dimasukkan penelitian korelasional, karena penelitian ini bertujuan untuk mengetahui hubungan antara variable bebas baik secara sendiri-sendiri maupun bersama-sama dengan variable terikatnya.

Populasi adalah kumpulan dari individu dengan kualitas dan ciri-ciri yang telah ditetapkan (Nazir, 1988). Keseluruhan kelompok orang yang memiliki kriteria tertentu sesuai dengan perhatian peneliti dinamakan populasi. Populasi adalah sekelompok manusia atau sesuatu yang betul-betul ada dan dirurnuskan dengan baik. Margono (2005) mengatakan bahwa populasi adalah keseluruhan objek penelitian sebagai sumber data yang memiliki karakteristik tertentu dalam suatu penelitian. Berdasarkan keempat pendapat di atas, dapat dinyatakan bahwa populasi ialah kumpulan dari individu yang memiliki kualitas dan ciri-ciri tertentu yang telah ditetapkan dan dirumuskan dengan baik, serta menjadi perhatian peneliti. Populasi dalam penelitian ini adalah seluruh siswa pada sekolah Menengah Pertama Negeri di Kecamatan Gerokgak tahun pelajaran 2017/2018 yang berjumlah sekitar 1.141 orang siswa.

Sampel adalah sebagian atau wakil dari populasi yang diteliti (Arikunto, 1997:46). Sampel adalah bagian dari jumlah dan karakteristik yang dimiliki oleh popilasi tersebut. Dari sejumlah populasi di atas diambil sejumlah sampel dengan teknik simple random sampling, yaitu suatu cara pengambilan sampel dari populasi yang dilakukan secara acak tanpa memperhatikan strata yang ada pada populasi tersebut. Hal ini peneliti gunakan mengingat populasi yang ada bersifat homogeny. Semakin banyak jumlah sampel hasil penelitian semakin baik (sugiyono, 2011: 81).

Variabel penelitian adalah segala sesuatu yang berbentuk apa saja yang ditetapkan oleh peneliti untuk dipelajari sehingga diperoleh informasi tentang hal tersebut, kemudian diambil kesimpulannya (Sugiyono, 2010). Dalam penelitian ini akan ditinjau dari lima variabel yaitu empat variable bebas, dan 1 variabel terikat. Variabel-variabel tersebut antara lain: variabel babas meliputi: status sosial ekonomi (X1), motivasi berprestasi (X2), budaya sekolah (X3), disiplin belajar (X4), dan hasil belajar $(\mathrm{Y})$ sebagai variabel terikat.

Alat pengumpul data harus memenuhi persyaratan yaitu syarat validitas dan reliabilitas dalam mengungkap apa yang hendak diukur. Ada dua persyaratan yang hendak digunakan dalam pengumpulan data penelitian yaitu validitas dan reliabilitas (Hamzah, 2007:63). Validitas instrumen dalam penelitian ini meliputi dua segi yaitu validitas isi dan validitas butir. Validitas isi dibantu oleh dua orang ahli/ expert, kemudian dianalisis dengan teknik Gregory.

Sebelum instrumen digunakan, maka perlu diuji dahulu validitas dari masing-masing pertanyaan yang ada sebagai alat pengambilan data. Dengan demikian terlebih dahulu diadakan uji coba terhadap kuisioner kemudian hasil uji coba ini dianalisis. Untuk menguji validitas butir rumus yang digunakan adalah rumus kontribusi product moment dari Pearson (Arikunto, 1995). 
Pengujian terhadap reabilitas instrumen dilakukan melalui pendekatan ketetapan internal. Uji reliabilitas adalah ketepatan dan keajegan alat pengukur tersebut dalam menilai apa yang diinginkan, artinya kapanpun alat tersebut digunakan akan diperoleh hasil yang sama (Puger, 2004). Pengujian reliabilitas dengan rumus Alpha dari Crombach (Arikunto, 1997:164).

Kegiatan analisis data terdiri atas kegiatan pengolahan data dan analisis statistik. Kegiatan analisis data meliputi: 1) menyunting data secara manual. Penyuntingan dilakukan karena kemungkinan ada data yang tidak jelas, atau kesalahan dalam pengisian instrument, sehingga tidak memenuhi syarat untuk dianalisis, 2) mentabulasi data, dan 3) mengolah data dalam bentuk sesuai kebutuhan.

Untuk menguji hipotesis yang telah dirumuskan, terlebih dahulu dilakukan analisis data yang telah dikumpulkan. Dalam melakukan analisis data untuk penelitian ini dilakukan dengan tiga tahapan yakni: 1) tahap deskripsi data, 2) tahap pengujian persyarat analisis, 3) tahap pengujian hipotesis.

Data yang telah diperoleh dari penelitian dideskripsikan menurut masing-masing variabel. Oleh tujuannya seperti itu, maka akan dicari harga rerata (M), standar deviasi (SD), modus (Mo), dan median (Me) setiap variabel yang diteliti.

Setelah data dideskripsikan, maka analisis dilanjutkan dengan menggunakan teknik regresi sederhana, regresi ganda, dan korelasi varsial. Persyaratan yang berkaitan dengan teknik analisis data tersebut harus dibuktikan secara statistik.

Setelah seluruh uji prasyarat terpenuhi, maka dilanjutkan dengan uji hipotesis. Untuk menguji hipotesis pertama, kedua, ketiga dan keempat dalam penelitian ini digunakan teknik analisis korelasi sederhana (korelasi product moment pearson). Sedangkan untuk menguji hipotesis ke empat, digunakan teknik analisis korelasi ganda, regresi ganda, dan korelasi parsial. Untuk menganalisis uji hipotesis dalam penelitian ini digunakan program SPSS-17.00 for windows.

\section{HASIL PENELITIAN DAN PEMBAHASAN}

\section{Kontribusi Status Sosial Ekonomi terhadap Hasil Belajar IPS Ekonomi pada Siswa} Kelas IX di SMP Kecamatan Gerokgak

Berdasarkan analisis data yang telah dilakukan, Secara normatif ditemukan bahwa status sosial ekonomi berada pada kategori sangat baik. Selain itu, hasil analisis juga menunjukkan bahwa terdapat korelasi yang signifikan antara status sosial ekonomi dengan hasil belajar IPS Ekonomi siswa kelas IX di SMP Kecamatan Gerokgak melalui persamaan garis regresi $\hat{y}=$ $33,780+0,458 \cdot X 1$ dengan Freg $=59,688(p<0,05)$. Sedangkan korelasi yang signifikan terjadi antara status sosial ekonomi dengan hasil belajar IPS Ekonomi sebesar 0,408 dengan $p<0,05$ dan variabel status sosial ekonomi dapat menjelaskan hasil belajar IPS Ekonomi siswa kelas IX di SMP Kecamatan Gerokgak sebesar 16,7\%. Temuan ini mengindikasikan bahwa status sosial ekonomi mempunyai peranan penting dalam meningkatkan hasil belajar IPS Ekonomi siswa kelas IX di SMP Kecamatan Gerokgak. Sumbangan efektif (SE) variabel status sosial ekonomi terhadap hasil belajar IPS Ekonomi siswa kelas IX di SMP Kecamatan Gerokgak adalah sebesar $8,64 \%$.

Temuan dalam penelitian ini sejalan dengan temuan penelitian yang dilakukan oleh Chotimah, dkk (2017) dalam penelitiannya yang berjudul Pengaruh Status Sosial Ekonomi Orang Tua Terhadap Prestasi Belajar Siswa (Studi Kasus Siswa Kelas VIII SMP Negeri 1 Jember Tahun Ajaran 2016/2017). Berdasarkan hasil penelitian data dan pembahasan yang telah dilakukan bahwa status sosial ekonomi orang tua berpengaruh terhadap prestasi belajar. Besarnya pengaruh status sosial ekonomi orang tua terhadap prestasi belajar siswa kelas VIII SMP Negeri 1 Jember Kabupaten Jember Tahun Ajaran 2016/2017 yaitu sebesar 77,3\%. Jadi status sosial ekonomi orang tua mempunyai pengaruh yang signifikan terhadap prestasi belajar siswa kelas VIII SMP Negeri 1 Jember Kabupaten Jember Tahun Ajaran 2016/2017.

Keberhasilan suatu kegiatan belajar yang dilakukan oleh setiap individu sangat dipengaruhi oleh beberapa faktor, yang dianggap cukup berpengaruh terhadap peningkatan 
hasil belajar siswa di sekolah adalah faktor status sosial ekonomi atau faktor keadaan ekonomi. Slameto (1991:65) menjelaskan bahwa "keadaan ekonomi keluarga erat hubungannya dengan hasil belajar anak. Kebutuhan-kebutuhan anak harus terpenuhi adalah : makanan, pakaian, kesehatan, dan fasilitas belajar seperti ruang belajar, meja, kursi, penerangan, buku-buku":. Fasilitas belajar ini hanya dapat terpenuhi jika orang tuanya mempunyai cukup uang.

Dari kutipan yang diungkap oleh Slameto jelas memberikan perbandingan gambaran antara siswa yang berada dalam kehidupan orang tua yang cukup mampu secara ekonomi akan mendukung atau mendorong bahkan dapat mengacu prestasi belajar seorang siswa jika dibandingkan dengan siswa yang berada dalam lingkungan keluarga yang kurang mampu. Siswa yang hidup di lingkungan keluarga di mana secara ekonomi orang tuanya dapat memenuhi kebutuhan hidupnya, karena tidak dapatlah dipungkiri bahwa salah satu yang mendukung kelancaran siswa menghadapi proses belajar adalah apabila terpenuhi kebutuhannya dalam hal ekonomi dalam menunjang prestasi belajar. Ruang lingkup status sosial ekonomi meliputi tingkat pendidikan dan tingkat pekerjaan (pendapatan) karena pendidikan dan pekerjaan seseorang pada zaman sekarang sangat mempengaruhi kekayaan atau perekonomian individu.

Keberhasilan suatu kegiatan belajar yang dilakukan oleh setiap individu sangat dipengaruhi oleh beberapa faktor yang dianggap cukup berpengaruh terhadap peningkatan hasil belajar siswa di sekolah adalah status sosial ekonomi yang terdiri dari: (1) tingkat pendidikan, (2) tingkat pendapatan, (3) jumlah tanggungan dalam keluarga.

Dari uraian tersebut terdapat hubungan yang saling berkaitan antar hasil belajar dengan status sosial ekonomi. Berdasarkan hal tersebut maka dapat diketahui terdapat kontribusi status sosial ekonomi terhadap hasil belajar siswa. Berdasarkan pemaparan di atas, maka dapat disimpulkan bahwa status sosial ekonomi memberikan kontribusi yang signifikan terhadap hasil belajar IPS Ekonomi pada siswa kelas IX di SMP Kecamatan Gerokgak.

\section{Kontribui Motivasi Berprestasi terhadap Hasil Belajar IPS Ekonomi pada Siswa Kelas IX di SMP Kecamatan Gerokgak}

Berdasarkan analisis data yang telah dilakukan, secara normatif ditemukan bahwa motivasi berprestasi berada pada kategori sangat baik. Selain itu, hasil analisis juga menunjukkan bahwa terdapat korelasi yang signifikan antara motivasi berprestasi dengan siswa kelas IX di SMP Kecamatan Gerokgak melalui persamaan garis regresi $\hat{y}=15,263+$ $0,386 \times 2$ dengan Freg $=58,958(p<0,05)$. Sedangkan korelasi yang signifikan terjadi antara motivasi berprestasi dengan hasil belajar IPS Ekonomi sebesar 0,406 dengan $\mathrm{p}<0,05$ dan variabel motivasi berprestasi dapat menjelaskan siswa kelas IX di SMP Kecamatan Gerokgak sebesar $16,5 \%$. Temuan ini mengindikasikan bahwa motivasi berprestasi mempunyai peranan penting dalam meningkatkan hasil belajar IPS Ekonomi siswa kelas IX di SMP Kecamatan Gerokgak. Sumbangan efektif (SE) variabel status sosial ekonomi terhadap hasil belajar IPS Ekonomi siswa kelas IX di SMP Kecamatan Gerokgak adalah sebesar 9,45\%.

Temuan dalam penelitian ini sejalan dengan temuan penelitian yang dilakukan oleh Widiantara (2013: 180) pada tesisnya yang berjudul Determinasi Kualitas Pengelolaan Pembelajaran, Disiplin Belajar, dan Motivasi Berprestasi Terhadap Hasil Belajar Bahasa Indonesia pada Siswa Kelas X di SMK PGRI 5 Denpasar disebutkan terdapat determinasi yang positif dan signifikan motivasi berprestasi terhadap hasil belajar Bahasa Indonesia melalui persamaan regresi $\hat{Y}=43,419+0,278 X^{3}$ dengan kontribusi sebesar $47,8 \%$ dan sumbangan efektif sebesar $20,10 \%$.

Prestasi belajar merupakan hasil yang dicapai seseorang untuk memperoleh perubahan pengetahuan, sikapmaupun keterampilan yang dinyatakan dalam bentuk simbol, angka, huruf maupun kalimat yang dapat mencerminkan hasil yang sudah dicapai oleh anak atau peserta didik dalam periode tertentu mengenai suatu sistem untuk menghasilkan informasi berkenaan dengan transaksi keuangan. Menurut Sardiman (2000: 89), hadiah dan angka (reward) 
mempengaruhi motivasi berprestasi. Motivasi berprestasi bersumber dari dorongan yang ada dalam diri siswa untuk melakukan kegiatannya sendiri yang berhubungan dengan proses belajar mengajar guna meraih keberhasilan setinggitingginya dalam prestasi akademiknya. Temuan dari Heckhausen, yang menunjukkan bahwa karakteristik individu yang mempunyai motivasi berprestasi antara lain yaitu berorientasi pada kesuksesan, berorientasi masa depan, suka tantangan, dan tangguh. Begitu pula, banyak yang dapat dilakukan terutama oleh guru untuk menumbuhkan motivasi berprestasi pada peserta didik. Menurut Sardiman (2000: 89) untuk menumbuhkan motivasi berprestasi dalam kegiatan belajar di sekolah dapat dilakukan dengan ; (1) memberikan angka / nilai, (2) hadiah, (3) memberi ulangan, (4) mengetahui hasil, (5) pujian dan hukuman.

Menurut Syah (2001: 132), faktor-faktor yang mempengaruhi motivasi berprestasi antara lain faktor internal (fisiologis: kondisi jasmani dan rohani,psikologis: tingkat kecerdasan siswa, sikap, bakat, minat, dan motivasi berprestasi), faktor eksternal (lingkungan sosial, non sosial) dan faktor pendekatan belajar. Syah (2001: 139) juga menambahkan salah satu faktor internal yang sangat mempengaruhi prestasi belajar adalah motivasi berprestasi.

Motivasi berprestasi mempunyai peranan yang sangat penting dalam menentukan hasil belajar siswa, sebab siswa yang mempunyai motivasi berprestasi tinggi mempunyai keinginan dan harapan untuk berhasil sehingga ia akan lebih meningkatkan perhatian konsentrasinya dalam menerima pelajaran. Hasil belajar yang ditunjukkan dengan prestasi belajar akan meningkat.

Berdasarkan pemaparan di atas, maka dapat disimpulkan bahwa motivasi berprestasi memberikan kontribusi yang signifikan terhadap hasil belajar IPS Ekonomi pada siswa kelas IX di SMP Kecamatan Gerokgak.

\section{Kontribui Budaya Sekolah terhadap Hasil Belajar IPS Ekonomi pada Siswa Kelas IX di SMP Kecamatan Gerokgak}

Berdasarkan analisis data yang telah dilakukan, secara normatif ditemukan bahwa budaya sekolah berada pada kategori sangat baik. Selain itu, hasil analisis juga menunjukkan bahwa terdapat korelasi yang signifikan antara budaya sekolah dengan hasil belajar IPS Ekonomi siswa kelas IX di SMP Kecamatan Gerokgak melalui persamaan garis regresi $\hat{y}=$ $20,309+0,341 \times 3$ dengan Freg $=38,793(p<0,05)$. Sedangkan korelasi yang signifikan terjadi antara budaya sekolah dengan hasil belajar IPS Ekonomi sebesar 0,339 dengan $p<0,05$ dan variabel budaya sekolah dapat menjelaskan hasil belajar IPS Ekonomi siswa kelas IX di SMP Kecamatan Gerokgak sebesar $11,5 \%$. Temuan ini mengindikasikan bahwa budaya sekolah mempunyai peranan penting dalam meningkatkan hasil belajar IPS Ekonomi siswa kelas IX di SMP Kecamatan Gerokgak. Sumbangan efektif (SE) variabel budaya sekolah terhadap hasil belajar IPS Ekonomi siswa kelas IX di SMP Kecamatan Gerokgak adalah sebesar 6,55\%.

Hasil penelitian ini sejalan dengan hasil penelitian yang dilakukan oleh Astuti (2015), dengan judul "Pengaruh Budaya Sekolah Terhadap Karakter Siswa Kelas X Jurusan Tata Boga SMK Negeri 3 Klaten". Hasil penelitian ini menunjukan bahwa: (1) Variabel keadaan budaya sekolah pada siswa kelas X jurusan tata boga SMK N 3 Klaten sebesar $45 \%$ termasuk dalam kategori cukup. Disebabkan oleh budaya membaca yang rendah yaitu sebesar $2 \%$, budaya saling percaya yaitu sebesar $4 \%$, budaya jujur sebesar $4 \%$, budaya kerja sama sebesar $5 \%$, budaya memberi penghargaan sebesar $6 \%$, budaya berprestasi sebesar $7 \%$, budaya bersih sebesar $8 \%$, dan budaya disiplin sebesar $9 \%$. (2) Variabel karakter siswa pada kelas X jurusan tata boga SMK N 3 Klaten sebesar $46 \%$ termasuk dalam kategori cukup. Rendahnya karakter gemar membaca yaitu sebesar $0,70 \%$, karakter semangat kebangsaan yaitu sebesar $0,85 \%$, karkater demokratis yaitu sebesar $0,90 \%$, karakter cinta tanah air yaitu sebesar $0,90 \%$, karakter kerja keras yaitu sebesar $0,95 \%$, karakter tanggung jawab yaitu sebesar $1 \%$, karakter mandiri yaitu $1 \%$, karakter menghargai prestasi yaitu 1,27\%, karakter jujur sebesar 1,50\%, karakter kreatif yaitu sebesar $2 \%$, karakter peduli sosial yaitu sebesar $2,50 \%$, karakter bersahabat sebesar 2,55\%, karakter cinta damai yaitu sebesar $2,80 \%$, karakter rasa ingin tahu 
sebesar $3 \%$, karakter toleransi sebesar $4 \%$, karakter religious sebesar $6 \%$, karakter peduli lingkungan sebesar $6 \%$ dan karakter disiplin sebesar 6\%. (3) Berdasarkan hasil uji hipotesis pada penelitian ini ditemukan hasil 30,2\% yang termasuk dalam kategori cukup sehingga bisa disimpulkan bahwa terdapat pengaruh yang cukup signifikan antara budaya sekolah terhadap karakter siswa kelas X jurusan boga SMK N 3 Klaten.

Mayer dan Rowen dalam Jamaluddin (2008: 24) menyatakan bahwa "budaya sekolah merupakan jiwa (spirit) sebuah sekolah yang memberikan makna terhadap kegiatan kependidikan sekolah tersebut, jika budaya sekolah lemah, maka ia tidak kondusif bagi pembentukan sekolah efektif". Sebaliknya budaya sekolah kuat maka akan menjadi fasilitator bagi peningkatan sekolah efektif.

Lebih lanjut Robbins (1994) mengungkapkan bahwa dalam lingkup tatanan dan pola yang menjadi karakteristik sebuah sekolah, kebudayaan memiliki dimensi yang dapat di ukur yang menjadi ciri budaya sekolah diantaranya yaitu : (1) Tingkat tanggung jawab, kebebasan dan independensi warga atau personil sekolah, komite sekolah dan lainnya dalam berinisiatif, (2) Sejauh mana para personil sekolah dianjurkan dalam bertindak progresif, inovatif dan berani mengambil resiko, (3) Sejauh mana sekolah menciptakan dengan jelas visi, misi, tujuan, sasaran sekolah, dan upaya mewujudkannya, (4) Sejauh mana unit-unit dalam sekolah didorong untuk bekerja dengan cara yang terkoordinasi, (5) Tingkat sejauh mana kepala sekolah memberi informasi yang jelas, bantuan serta dukungan terhadap personil sekolah, (6) Jumlah pengaturan dan pengawasan langsung yang digunakan untuk mengawasi dan mengendalikan perilaku personil sekolah, (7) Sejauh mana para personil sekolah mengidentifkasi dirinya secara keseluruhan dengan sekolah ketimbang dengan kelompok kerja tertentu atau bidang keahlian professional, (8) Sejauh mana alokasi imbalan diberikan didasarkan atas kriteria prestasi, (9) Sejauh mana personil sekolah didorong untuk mengemukakan konflik dan kritik secara terbuka, dan (10) Sejauh mana komunikasi antar personil sekolah dibatasi oleh hierarki yang formal.

Dari beberapa karakteristik yang ada, dapat dikatakan bahwa budaya sekolah bukan hanya refleksi dari sikap para personil sekolah, namun juga merupakan cerminan kepribadian sekolah yang ditunjukan oleh perilaku individu dan kelompok dalam sebuah komunitas sekolah. Hal tersebut mempunyai pengaruh terhadap hasil belajar siswa, jika kondisi sekolah kondusif dan efektif maka siswa akan fokus mendapatkan proses pembelajaran secara maksimal dan pencapaian hasil belajar pun akan maksimal.

Dari uraian tersebut terdapat hubungan yang saling berkaitan antar budaya sekolah dengan hasil belajar siswa. Berdasarkan hal tersebut maka dapat diketahui terdapat kontribusi budaya sekolah guru terhadap hasil belajar siswa. Berdasarkan pemaparan di atas, maka dapat disimpulkan bahwa budaya sekolah memberikan kontribusi yang signifikan terhadap hasil belajar IPS Ekonomi pada siswa kelas IX di SMP Kecamatan Gerokgak.

\section{Kontribusi Disiplin Belajar terhadap Hasil Belajar IPS Ekonomi pada Siswa Kelas IX di SMP Kecamatan Gerokgak}

Berdasarkan analisis data yang telah dilakukan, secara normatif ditemukan bahwa disiplin belajar berada pada kategori sangat baik. Selain itu, hasil analisis juga menunjukkan bahwa terdapat korelasi yang signifikan antara disiplin belajar dengan hasil belajar IPS Ekonomi siswa kelas IX di SMP Kecamatan Gerokgak melalui persamaan garis regresi $\hat{y}=50,942+0,386 X 4$ dengan Freg $=79,025(p<0,05)$. Sedangkan korelasi yang signifikan terjadi antara disiplin belajar dengan hasil belajar IPS Ekonomi sebesar 0,219 dengan $p<0,05$ dan variabel budaya sekolah dapat menjelaskan hasil belajar IPS Ekonomi siswa kelas IX di SMP Kecamatan Gerokgak sebesar 43,9\%. Temuan ini mengindikasikan bahwa disiplin belajar mempunyai peranan penting dalam meningkatkan hasil belajar IPS Ekonomi siswa kelas IX di SMP Kecamatan Gerokgak. Sumbangan efektif (SE) variabel disiplin belajar terhadap hasil belajar IPS Ekonomi siswa kelas IX di SMP Kecamatan Gerokgak adalah sebesar 2,95\%. 
Demikian juga halnya pada penelitian tesis yang berjudul Kontribusi Kualitas Pembelajaran, Motivasi Berprestasi, dan Kedisiplinan Belajar Terhadap Prestasi Belajar Reservasi yang dilakukan oleh Miswati (2012: 138) disebutkan terdapat kontribusi yang signifikan antara motivasi berprestasi terhadap prestasi belajar memproses reservasi pada siswa kelas XII SMK Negeri 4 Denpasar tahun pelajaran 2011/2012. Hasil perhitungan regresi sederhana $Y$ atas $X^{2}$ dengan persamaan regresi $\hat{Y}=52,594+0,181 X^{2}$ dengan $F$ hitung $=$ 41,080 dan $F 67,894$ dan $F$ table $=3,960$. Karena $F$ hitung $>F$ table, maka hubungan kedua variable tersebut dikatakan signifikan dan linier.

Untuk menumbuhkan sikap disiplin dalam belajar, perlu adanya kebiasaan melatih diri. Dengan disiplin dalam belajar, kondisi kelas akan aman, tertib, bersih, dan damai, sehingga dapat membantu siswa untuk dapat mengingat, berpikir, dan merasa dengan baik dikelas saat kegiatan belajar mengajar berlangsung.

Ketertiban kelas dapat di wujudkan dengan baik apabila ditentukan oleh sikap disiplin warga kelas, dalam hal ini yaitu siswa dan guru. Karena itu, guru haruslah terlebih dahulu mampu menunjukan sikap disiplin karena setiap tingkah laku seorang guru akan ditiru oleh siswanya. Setelah itu, barulah seorang guru dituntut mampu untuk memilih dan menerapkan strategi disiplin yang mampu menjamin terciptanya ketertiban didalam suatu kelas. Disiplin dalam hal ini dimaksudkan adalah "usaha untuk membina secara terus menerus kesadaran dalam bekerja atau belajar dengan baik dalam arti setiap orang menjalankan fungsinya dengan efektif".

Berdasarkan kajian teori yang sudah dipaparkan diatas maka disiplin belajar dapat dibagi menjadi beberapa indikator untuk bisa mencapi hasil belajar yang maksimal yaitu :

a. Ketaatan terhadap tata tertib sekolah dengan indikator: (1) Kehadiran siswa (2) Penggunaan pakaian seragam sekolah (3) Lingkungan sekolah (4) Etika, Estetika dan Sopan Santun (5) Administrasi Sekolah (6) Kegiatan Ekstrakulikuler dan Pengembangan diri (7) Melaksanakan tugas piket sesuai jadwal

b. Ketaatan terhadap kegiatan belajar di sekolah dengan indikator: (1) Tidak melakukan keributan dikelas (2) Mengikuti kegiatan pembelajaran yang diadakan sekolah (3) Tidak mencontek saat ulangan

c. Ketaaatan dalam mengerjakan tugas-tugas pelajaran dengan indikator: (1) Mengerjakan tugas yang diberikan oleh guru (2) Mengumpulkan tugas tepat waktu

d. Ketaatan terhadap kegiatan belajar di rumah dengan indikator: (1) Belajar saat ada waktu luang (2) Mengerjakan tugas pekerjaan rumah (PR).

Kedisiplinan belajar siswa mempunyai peranan dalam menunjang terlaksananya proses belajar mengajar yang baik, sehingga akan memunculkan sikap belajar yang baik pada diri siswa. Kedisiplinan belajar sangatlah penting bagi siswa, karena siswa harus dapat mencapai tujuan belajarnya yaitu untuk mendapatkan hasil belajar yang maksimal.

\section{Kontribusi Status Sosial Ekonomi, Motivasi Berprestasi, Budaya Sekolah, Disiplin Belajar, secara Simultan terhadap Hasil Belajar IPS Ekonomi pada Siswa Kelas IX di SMP Kecamatan Gerokgak}

Berdasarkan analisis yang telah dilakukan, ditemukan bahwa terdapat korelasi yang signifikan secara bersama-sama antara status sosial ekonomi, motivasi berprestasi, budaya sekolah, dan disiplin belajar terhadap hasil belajar IPS Ekonomi melalui persamaan garis regresi $\hat{y}=31,818+0,237 X 1+0,221 X 2+0,194 X 3+0,134 X 4$ dengan Freg $=28,114(p<0,05)$. Ini berarti terdapat hubungan secara bersama-sama antara status sosial ekonomi, motivasi berprestasi, budaya sekolah, dan disiplin belajar terhadap hasil belajar IPS Ekonomi siswa kelas IX di SMP Kecamatan Gerokgak. Hal ini mengindikasikan bahwa makin baik status sosial ekonomi, motivasi berprestasi, budaya sekolah, dan disiplin belajar makin baik pula hasil belajar IPS Ekonomi tersebut.

Dalam penelitian ini kontribus status sosial ekonomi untuk bisa mencapai hasil belajar yang maksimal dapat dibagi menjadi 3 indikator, yaitu : (1) tingkat pendidikan, (2) tingkat 
pendapatan, (3) jumlah tanggungan dalam keluarga. Motivasi berprestasi mempunyai peranan yang sangat penting dalam menentukan hasil belajar siswa, Menurut Sardiman (2000: 89) untuk menumbuhkan motivasi berprestasi dalam kegiatan belajar di sekolah agar tercapai hasil belajar yang maksimal dapat dilakukan dengan ; (1) memberikan angka / nilai, (2) hadiah, (3) memberi ulangan, (4) mengetahui hasil, (5) pujian dan hukuman. Mayer dan Rowen dalam Jamaluddin (2008: 24) menyatakan bahwa "budaya sekolah merupakan jiwa (spirit) sebuah sekolah yang memberikan makna terhadap kegiatan kependidikan sekolah tersebut, jika budaya sekolah lemah, maka ia tidak kondusif bagi pembentukan sekolah efektif'. Sebaliknya budaya sekolah kuat maka akan menjadi fasilitator bagi peningkatan sekolah efektif sehingga hasil belajar sesuai dengan yang diharapkan. Menurut Hadari Nawawi , dalam Juliandi (2014: 5), disiplin belajar hal ini dimaksudkan adalah "usaha untuk membina secara terus menerus kesadaran dalam bekerja atau belajar dengan baik dalam arti setiap orang menjalankan fungsinya dengan efektif". Kedisiplinan belajar siswa mempunyai peranan dalam menunjang terlaksananya proses belajar mengajar yang baik, sehingga akan memunculkan sikap belajar yang baik pada diri siswa. Kedisiplinan belajar sangatlah penting bagi siswa, karena siswa harus dapat mencapai tujuan belajarnya yaitu untuk mendapatkan hasil belajar yang maksimal.

Dengan demikian secara simultan dari empat variable bebas penelitian ini secara simultan terdapat hubungan terhadap hasil belajar, status sosial ekonomi dapat berkorelasi dengan hasil belajar, motivasi berprestasi berkorelasi dengan hasil belajar, dan disiplin belajar berkorelasi pula terhadap hasil belajar.

Korelasi murni antara status sosial ekonomi, motivasi berprestasi, budaya sekolah, dan disiplin belajar dengan hasil belajar IPS Ekonomi siswa kelas IX di SMP Kecamatan Gerokgak yang diperoleh melalui analisis korelasi parsial jenjang kedua. Hasil yang diperoleh adalah: pertama, terdapat korelasi yang signifikan antara variabel status sosial ekonomi terhadap hasil belajar IPS Ekonomi dengan dikendalikan oleh variabel motivasi berprestasi, budaya sekolah, dan disiplin belajar $\left(r_{1 y-234}=0,408\right)$ dengan $\left.p<0,05\right)$. Ini menunjukkan bahwa status sosial ekonomi memberikan kontribusi yang signifikan terhadap hasil belajar IPS Ekonomi siswa kelas IX di SMP Kecamatan Gerokgak, sehingga dapat dijadikan prediktor kecenderungan tingkat hasil belajar IPS Ekonomi siswa kelas IX di SMP Kecamatan Gerokgak.

Kedua, terdapat korelasi yang signifikan motivasi berprestasi terhadap hasil belajar IPS Ekonomi dengan dikendalikan oleh variabel status sosial ekonomi, budaya sekolah, dan disiplin belajar $\left(r_{2 y-134}=0,406\right.$ dengan $\left.p>0,05\right)$. Ini menunjukkan bahwa motivasi berprestasi memberikan kontribusi terhadap hasil belajar IPS Ekonomi siswa kelas IX di SMP Kecamatan Gerokgak, sehingga dapat dijadikan prediktor kecenderungan tingkat hasil belajar IPS Ekonomi siswa kelas IX di SMP Kecamatan Gerokgak.

Ketiga, terdapat korelasi yang signifikan antara budaya sekolah terhadap hasil belajar IPS Ekonomi dengan dikendalikan oleh variabel status sosial ekonomi, motivasi berprestasi, dan disiplin belajar $\left(r_{3 y-124}=0,339\right.$ dengan $\left.p>0,05\right)$. Ini menunjukkan bahwa budaya sekolah memberikan kontribusi terhadap hasil belajar IPS Ekonomi siswa kelas IX di SMP Kecamatan Gerokgak, sehingga dapat dijadikan prediktor kecenderungan tingkat hasil belajar IPS Ekonomi siswa kelas IX di SMP Kecamatan Gerokgak.

Keempat, terdapat korelasi yang signifikan antara disiplin belajar terhadap hasil belajar IPS Ekonomi dengan dikendalikan oleh variabel status sosial ekonomi, motivasi berprestasi dan budaya sekolah $\left(r_{4 y-123}=0,219\right.$ dengan $\left.p>0,05\right)$. Ini menunjukkan bahwa disiplin belajar memberikan kontribusi terhadap hasil belajar IPS Ekonomi siswa kelas IX di SMP Kecamatan Gerokgak, sehingga dapat dijadikan prediktor kecenderungan tingkat hasil belajar IPS Ekonomi siswa kelas IX di SMP Kecamatan Gerokgak.

Kekuatan hubungan keempat variabel bebas dengan hasil belajar IPS Ekonomi siswa kelas IX di SMP Kecamatan Gerokgak secara berurutan adalah: status sosial ekonomi, motivasi berprestasi, budaya sekolah, dan disiplin belajar mempunyai kontribusi terhadap hasil belajar IPS Ekonomi. 


\section{PENUTUP}

Berdasarkan hasil penelitian dan pembahasan yang telah dilakukan, maka dapat ditarik kesimpulan sebagai berikut.

Pertama, ada kontribusi yang signifikan antara status sosial ekonomi terhadap hasil belajar IPS Ekonomi pada siswa kelas IX di SMP Kecamatan Gerokgak dengan koefisien korelasi sebesar 0,408 dan sumbangan efektifnya sebesar 8,64\%.

Kedua, ada kontribusi yang signifikan antara motivasi berprestasi terhadap hasil belajar IPS Ekonomi pada siswa kelas IX di SMP Kecamatan Gerokgak. dengan koefisien korelasi sebesar 0,406 dan sumbangan efektifnya sebesar 9,45\%.

Ketiga, ada kontriubusi yang signifikan antara budaya sekolah terhadap hasil belajar IPS Ekonomi pada siswa kelas IX di SMP Kecamatan Gerokgak dengan koefisien korelasi sebesar 0,339 dan sumbangan efektifnya sebesar $6,55 \%$.

Keempat, ada kontriubusi yang signifikan antara disiplin belajar terhadap hasil belajar IPS Ekonomi pada siswa kelas IX di SMP Kecamatan Gerokgak dengan koefisien korelasi sebesar 0,219 dan sumbangan efektifnya sebesar 2,95\%.

Kelima, secara bersama-sama, ada kontribusi yang signifikan antara status sosial ekonomi, motivasi berprestasi, budaya sekolah, dan disiplin belajar terhadap hasil belajar IPS Ekonomi pada siswa kelas IX di SMP Kecamatan Gerokgak dengan koefisien korelasi ganda sebesar 0,525 dan kontribusinya sebesar 27,6\% terhadap hasil belajar IPS Ekonomi siswa kelas IX di SMP Kecamatan Gerokgak.

Berdasarkan hasil dan kesimpulan dari penelitian ini, dapat diajukan beberapa saran sebagai berikut.

Siswa seharusnya dapat meningkatkan motivasi berprestasi dan disiplin belajarnya agar dapat meningkatkan hasil belajar mereka.

Orang tua hendaknya mampu untuk meningkatkan status sosial ekonomi keluarganya, sehingga dapat berkontribusi positif terhadap hasil belajar siswa.

Guru hendaknya mampu untuk meningkatkan budaya sekolah yang ada. Pengembangan budaya sekolah yang kuat, intim, kondusif, dan bertanggung jawab membawa manfaat untuk menjamin kualitas kerja yang lebih baik.

Peneliti lain diharapkan mampu mengembangkan variabel lain dalam usaha meningkatkan hasil belajar IPS Ekonomi, sehingga dapat mengembangkan ilmu pengetahuan ke arah yang lebih baik.

\section{DAFTAR RUJUKAN}

Arikunto, Suharsimi. 1995. Manajemen Penelitian. Jakarta: Rineka Cipta.

Arikunto, Suharsimi. 1997. Prosedur Penelitian Suatu Pendekatan Praktek. Jakarta: Rineka

Astuti, Albertin Dwi. 2015. Pengaruh Budaya Sekolah Terhadap Karakter Siswa Kelas X Jurusan Tata Boga SMK Negeri 3 Klaten. Tesis. Universitas Negeri Yogyakarta.

Chotimah, dkk. 2017. Pengaruh Status Sosial Ekonomi Orang Tua Terhadap Prestasi Belajar Siswa (Studi Kasus Siswa Kelas VIII SMP Negeri 1 Jember Tahun Ajaran 2016/2017). Tesis.

Dantes, Nyoman. 2012. Metode Penelitian. Yogyakarta: Andi.

Davis, G. \& Thomas, M. 1996. Effectif School and Effective Teacher. Boston: Allyn \& Bacon

Dimyati dan Mudjiono. 1999. Belajar dan Pembelajaran. Jakarta: Rineka Cipta. 
Hamalik, Oemar. 2006. Proses Belajar Mengajar. Bandung: PT Bumi Aksara.

Hamzah, B. Uno. 2007. Teori Motivasi dan Pengukurannya. Jakarta: Bumi Aksana.

Hasbullah, 2002. Dasar-dasar IImu Pendidikan. Jakarta: PT. Raja Grafindo Persada

Jamaluddin, Ahmad. 2008. Metode Penelitian Administrasi Publik (Teori dan Aplikasi). Yogyakarta: Penerbit Gava Media

Margono, S. 2005. Metodologi Penelitian Pendidikan. Jakarta: PT. Rineka Cipta

Miswati. 2012. Kontribusi Kualitas Pembelajaran, Motivasi Berprestasi, dan Kedisiplinan Belajar Terhadap Prestasi Belajar. Tesis.

Nazir, Muhammad. 1988. Metode Penelitian. Jakarta:Ghalia Indonesia

Puger, I Gusti Ngurah. 2004. Belajar Kooperatif. Diktat Perkuliahan Mahasiswa Unipas.

Robbins, Stephen P. 1994. Perilaku Organisasi, Konsep, Kontroversi dan Aplikasi. Alih Bahasa : Hadyana Pujaatmaka. Edisi Keenam. Jakarta: PT.Bhuana IImu Populer.

Sardiman. 2000. Interaksi \& Motivasi Belajar Mengajar. Jakarta: Rajawali Pers.

Sardiman. 2011. Interaksi dan Motivasi Belajar . Jakarta : Rajagrafindo Persada

Slameto. 1991. Belajar dan Fakor-faktor yang Mempengaruhi. Jakarta: Rieneka Cipta

Slavin, Robert E. 2001. Educational Psychology: Theory and Practice.Pearson. New Jersey: Education.

Sugiyono. 2010. Metode Penelitian Administrasi: Pendekatan Kuantitatif, Kualitatif, dan R\&D. Bandung: Alfabeta

Widiantara. 2013. Determinasi Kualitas Pengelolaan Pembelajaran, Disiplin Belajar, dan Motivasi Berprestasi Terhadap Hasil Belajar Bahasa Indonesia pada Siswa Kelas X di SMK PGRI 5 Denpasar. Tesis.

Woolfolk. 2000. Educational Psychology. Boston: Pearson Educational. 